\title{
Competitive Environment Analysis in Global Retail Companies Operation Strategy: A Data Envelopment Analysis (DEA) Based Approach
}

\author{
Zainal Putra ${ }^{1 *}$ and Muzakir ${ }^{2}$ \\ 1,2 Universitas Teuku Umar, Aceh Barat, Indonesia
}

\begin{abstract}
This research aims to find out the most competitive retail company operating in current global market based on the perspective of efficiency. A well-performed company is the company that is efficient in its operations. By using Data Envelopment Analysis (DEA) approach, this research differs from prior research because we used multivariable inputs, namely: asset, operational expense and the number of employees. The output variables used in this research are: total revenue, net profit, return on equity (ROE), return on assets (ROA), return on investment (ROI), dividend yield ratio and asset turnover ratio. The analysis results shows that six retail companies are "efficient" in its operation (efficiency score of 1.00), namely: Carrefour, Costco, Kroger Company, Home Depot Inc, JD.com Inc Adr and Alibaba Group Holdings Ltd ADR. Therefore, these companies are considered the most competitive in its operation strategy in the current global market, whereas there are four retail companies falls into category of "inefficient" (efficiency score < 1.00), namely: Walmart, Amazon.com Inc, Tesco PLC and Walgreens Boots Alliance Inc.
\end{abstract}

Keywords: Competitive, DEA, Efficient, Retail

\section{Introduction}

Retailing serves the selling of goods and services toward the consumers, both for household and personal consumption. There are various types of goods available in retail shops, including: food, clothes, electronics, drugs, books, and many others (Marketos \& Theodoridis, 2006).

Retail industry has a long process of supply chain, starting from supplier, importer, producer, distributor, wholesaler, and retailer. Thus the retail store is at the very end of the supply chain. Based on its supply chain, retailer directly interact with the end-consumers. Advances in information technology have been applied in this sector, both for data management, supply chain, and also in terms of marketing strategies. As the result, the consumers can enjoy a quick and quality services.

The retail industry is one of the sectors that is most sought after by capital owners. With a high level of sales, they managed to reap relatively large profits at the end of each year. One of the reasons is because this industry usually provides essential goods for the needs of the community. In 2019, Walmart as a giant retailer, ranked first in the largest revenue, amounting to US\$ 127,991 million, followed by Amazon and Carrefour, each of which managed to record revenues of US\$ 87,436 million and US\$ 41,611 million.

Regarding the top three retail companies which managed to record the largest revenue in 2019, we will briefly review the company's profile. The first is Walmart; the largest retail company in the world headquartered in Bentonnile, Akansas, United

* Corresponding author. Email address: zainalputra@utu.ac.id 
States. The company was established on July 2, 1962 by Sam Walton. Currently, Walmart has 11,690 outlets worldwide employing 2,200,000 employees. The second is Amazon; This e-commerce company based in Seattle Washington was established by Jeff Bezos on July 5, 1994. The company, operating under amazone.com, has separate retail websites in various countries. For example, for India, the website name is Amazon.in, and so on. Amazon has 534 outlets around the globe, employing 798,000 employees. The third is Carrefour, a retail company headquartered in BoulognrBillancourt, France. Established on January 1, 1958 by Marcel Fournier, Denis Defforey, and Jacques Defforey, Carrefour now are operating in America, Asia, and Africa. Carrefour has around 11,935 outlets worldwide and now employs 321,383 employees.

One interesting thing to note is that in terms of its revenue, Alibaba was ranked tenth in 2019 as the company managed to make a profit of US\$ 7,397 million. This means that of the top ten retail companies operating in the global market, Alibaba has been ranked first in terms of profitability. Alibaba is an e-commerce giant headquartered in Binjiang District, Hangzhou, China. The company, founded by Jack Ma in 1999, now employs 116,519 employees. The top ten global retail companies based on revenue in 2019 are presented below.

Table 1 Top Ten Global Retail Companies Based on the Biggest Revenue in 2019

\begin{tabular}{clcc}
\hline No & \multicolumn{1}{c}{ Companies } & $\begin{array}{c}\text { Revenue } \\
\text { (Million USD) }\end{array}$ & $\begin{array}{c}\text { Net Profit } \\
\text { (Million USD) }\end{array}$ \\
\hline 1. & Walmart & 127,991 & 3,288 \\
2. & Amazon.com Inc & 87,436 & 3,268 \\
3. & Carrefour SA & 41,611 & 1,719 \\
4. & Tesco PLC & 39,864 & 405 \\
5. & Costco & 37,040 & 844 \\
6. & Walgreens Boots Alliance Inc & 34,339 & 844 \\
7. & Kroger Company & 27,974 & 263 \\
8. & Home Depot Inc & 27,223 & 2,769 \\
9. & JD.com Inc Adr & 24,135 & 514 \\
10. & Alibaba Group Holdings Ltd ADR & 22,830 & 7,397 \\
\hline \hline
\end{tabular}

Source: summarized from https://id.investing.com

In this regard, the researchers conclude that it is very important for company managers to conduct an environmental analysis to maintain a sustainable competitive advantage, including retail industry sector. In line with what Birkinshaw, Morrison, \& Hulland (1995) suggest, that the analysis of the competitive environment is very important for corporate strategy, business strategy and competitive strategy in the global market. This statement also supported by Ward \& Duray (2000) and Gong (2013), who emphasized that analysis of the competitive environment is very important for decision making in global retail organizations.

Previous research on the importance of analyzing the competitive environment for companies in an industry has been carried out using a variety of methods, both using qualitative and quantitative methods, some of which we present in the table below. 
Competitive Environment Analysis in Global Retail Companies Operation Strategy: A

Data Envelopment Analysis (DEA) Based Approach

Table 2 Previous Research Related to Competitive Environmental Analysis

\begin{tabular}{|c|c|c|c|}
\hline Researchers & Theme & Method & Industry/Sector \\
\hline $\begin{array}{l}\text { Birkinshaw et al. } \\
\text { (1995) }\end{array}$ & $\begin{array}{l}\text { Structural and competitive determinants } \\
\text { of a global integration strategy }\end{array}$ & $\begin{array}{l}\text { Partial Least } \\
\text { Square (PLS) } \\
\text { Models }\end{array}$ & Trade Industry \\
\hline Geys (2006) & $\begin{array}{l}\text { Looking Across Borders: A Test of } \\
\text { Spatial Policy Interdependence Using } \\
\text { Local Government Efficiency Ratings }\end{array}$ & $\begin{array}{l}\text { Spatial Lag } \\
\text { Model }\end{array}$ & Goverment \\
\hline Burt et al. (2011) & $\begin{array}{l}\text { Standardized Marketing Strategies in } \\
\text { Retailing? IKEA's Marketing Strategies } \\
\text { in Sweden, the UK and China }\end{array}$ & $\begin{array}{l}\text { IKEA's } \\
\text { marketing } \\
\text { strategy }\end{array}$ & $\begin{array}{l}\text { Retail outlets } \\
\text { operating in } \\
\text { Sweden, UK, } \\
\text { and China }\end{array}$ \\
\hline Pang et al. (2013) & $\begin{array}{l}\text { Information Technology and } \\
\text { Administrative Efficiency in U.S. State } \\
\text { Governments - A Stochastic Frontier } \\
\text { Approach Min-Seok }\end{array}$ & $\begin{array}{l}\text { Stochastic } \\
\text { Frontier } \\
\text { Approach }\end{array}$ & Goverment \\
\hline $\begin{array}{l}\text { Ahmad et al. } \\
\text { (2014) }\end{array}$ & $\begin{array}{l}\text { A Comparative Study on Service } \\
\text { Quality in the Grocery Retailing: } \\
\text { Evidence from Malaysia and Turkey }\end{array}$ & $\begin{array}{l}\text { Comparative } \\
\text { Study }\end{array}$ & $\begin{array}{l}\text { Grocery } \\
\text { retailing in } \\
\text { Malaysia and } \\
\text { Turkey }\end{array}$ \\
\hline Ko et al. (2017) & $\begin{array}{l}\text { Efficiency Analysis of Retail Chain } \\
\text { Stores in Korea }\end{array}$ & $\begin{array}{l}\text { Data } \\
\text { Envelopment } \\
\text { Analysis (DEA) } \\
\text { and Tobit } \\
\text { Regression Model }\end{array}$ & $\begin{array}{l}\text { Household } \\
\text { retailer in Korea }\end{array}$ \\
\hline Liu et al. (2018) & $\begin{array}{l}\text { A DEA-Based Approach for } \\
\text { Competitive Environment Analysis in } \\
\text { Global Operations Strategies }\end{array}$ & $\begin{array}{l}\text { Data } \\
\text { Envelopment } \\
\text { Analysis (DEA) }\end{array}$ & $\begin{array}{l}\text { Global retail } \\
\text { outlets }\end{array}$ \\
\hline Gong et al. (2019) & $\begin{array}{l}\text { When to Increase Firms' Sustainable } \\
\text { Operations for Efficiency? A Data } \\
\text { Envelopment Analysis in the Retailing } \\
\text { Industry }\end{array}$ & $\begin{array}{l}\text { Data } \\
\text { Envelopment } \\
\text { Analysis (DEA) }\end{array}$ & $\begin{array}{l}\text { Global retailing } \\
\text { industry }\end{array}$ \\
\hline
\end{tabular}

In this study, we conduct an analysis of the competitive environment through an efficiency perspective. Retail companies that are considered the most competitive are those who are most efficient in their operating strategies in a global market environment. We measure it with the Data Envelopment Analysis (DEA) approach.

To the best of our knowledge, this research is different from the previous mentioned researches, especially in terms of the measurement approach used. Although some previous studies as shown in the above table also have used the DEA approach, the input and output variables are different. As research by Ko et al. (2017), the input used in its DEA model is: store size, number of items, number of employees and rental costs. While the output used is sales revenue and number of customers.

As research by Liu et al. (2018), the input used in tis DEA model is: outlets, warehouses, supplier and inhabitants. While the output used is market concentration, consumer spending and market share. As research by Gong et al. (2019) the input used in its DEA model is: supply chain coordination and sustainability level. While the output used is: cost competency, flexibility competency, social competency, environmental competency and business performance. This research is different from the previous researches since in this research we used multiple input variables, namely: assets, operating costs and number of employees. We also use multi output variables, namely: total revenue, net profit, ROE, ROA, ROI, dividend payout ratio and asset turnover ratio. 
Based on the gap research we feel it is very important to conduct this research, with the aim of: first, to find out the most competitive retail companies operating in today's global market environment, viewed from an efficiency perspective. A wellperformed company is the company that is efficient in its operations. Second, trying to give a picture of solutions to companies that are not yet competitive/efficient, on how to improve their performance.

\section{Literature Review}

\subsection{Competitive Environment Analysis}

Basically, strategic management is about how to obtain and maintain competitive advantage. This term can be interpreted as anything that can be done much better by a company when compared with rival companies (David \& David, 2017). In strategic management theory, it is emphasized that to be able to maintain its competitive advantage, organizations must adapt to their environment. This has long been echoed by Ginter \& Duncan (1990), that environmental analysis is an integral and very important part of the strategic planning process itself. Furthermore, David \& David (2017) stated that one important part of the analysis of the external environment is identifying competing companies, determining their strengths, weaknesses, capabilities, opportunities, threats, goals and strategies.

Wheelen, Hunger, Hoffman, \& Bamford (2018) assert that it is essential for the managers to understand the environmental context in which their organizations compete before formulating business strategy. It is impossible for companies to design strategies without a deep understanding of the external environment. Wheelen et al. (2018) further explains that environmental scanning is a comprehensive term that includes monitoring, evaluating, and disseminating information relevant to the development of organizational strategy. After management has captured all aspects of the external environment that have an impact on the business, then the company's competitive advantage can be determined.

Industry is defined as a group of companies that produce similar products or services, such as soft drinks or financial services. Conducting an analysis of stakeholder groups in an industry is very important, for example an analysis of suppliers and customers in the environment of a particular company is part of the industry analysis.

Meanwhile Hitt, Ireland, \& Hoskisson (2017) explained that to achieve strategic competitiveness, companies must formulate and implement a value creation strategy. Strategy is a set of commitments and integrated and coordinated actions designed to exploit core competencies and gain competitive advantage. However, to achieve competitive advantage, the company must be responsive to the changing environment. In fact, even adapting to the local environment, sometimes companies have to make big changes. One of the companies which adopted and demonstrated this strategic is Abibaba, which has now become a leader in its industry as one of the most successful online sales facilitators in China and is striving to become a successful global business.

According to Hitt et al. (2017) a company achieves competitive advantage when they are able to implement strategies that create superior value for customers and cannot be duplicated by the competitors or are too expensive to emulate. However, it is important to note that there is no permanent competitive advantage in the company.

In 1997, Russo \& Fouts conducted a research on the relationship between the company's environmental performance and the level of profit generated (profitability). The results indicate that: a) a high level of environmental performance is associated with increased profitability; b) the greater the company's growth, the greater the positive impact of environmental performance on company profitability. Russo \& Fouts (1997) links corporate environmental performance with three aspects, namely: a) physical assets and technology; b) human resources and organizational capabilities; and c) intangible resources. Where intangible resources are the reputation of leadership 
in caring for the environment, so that ultimately it can increase sales among customers who are sensitive to the problem (environment) (Russo \& Fouts, 1997).

A research by McKinsey \& Company in 2011 found that an analysis of the external environment was the most important information for executives to consider when developing company strategies. The results prove that there is a positive relationship between environmental analysis and profit (Wheelen et al., 2018). Golovko \& Valentini (2011) found out that internal environmental factors, in this case innovation has a positive effect on company growth. Other research by Pang et al. (2013) shows evidence that environmental factors such as market share, rural populations and politically divided governments have a moderate effect on the relationship between information technology and administrative efficiency, and several environmental factors that are treated as control variables in their research, such as population, household income and gross domestic product (GDP), also have an influence on operational efficiency.

\subsection{Data Envelopment Analysis (DEA)}

DEA has been widely studied, used and analyzed by academics who understand linear programming. DEA was developed to measure organizational performance. This technique has been used successfully to assess the performance of a number of organizations that use a variety of similar inputs and also produce the same variety of outputs. The efficiency measured in DEA is known as Decision-Making Unit (DMU). Jadi DEA measures how efficient a DMU is in using available resources to produce a set of outputs. Linear programming is the underlying methodology that makes DEA very powerful when compared to other alternative productivity management tools. DMU can include manufacturing units, large organizations such as universities, schools, bank branches, hospitals, police stations, tax offices, companies and so on. The DMU performance assessed in DEA uses the concept of efficiency or productivity, which is the ratio of total output to total input. The best performing DMUs are given an efficiency score of one or 100 percent (Ramanathan, 2003).

Taylor III (2016) also states that DEA is a linear programming application that compares a number of service units of the same type, such as banks, hospitals, restaurants and schools based on their inputs and outputs. The results of the model solution indicate whether certain units are less productive, or inefficient, compared to other units. For example, DEA has compared hospitals where input includes hospital beds and staff size and output including patient days for different age groups.

Liu et al. (2018) explain that DEA is an important non-parametric method in management of production and operations. As an optimization method, DEA enables multi-input, multi-output measurement of the relative performance of production units and has been widely used to assess operational performance in various industries.

In the classical DEA model there is an implicit assumption that all inputs and outputs are 'discretionary variables', which can vary depending on the policy of the company manager. The non-discretionary DEA model seeks to overcome the problem of input from the external environment. Input 'non-discretionary variables' (Cooper, Seifod, \& Tone, 2006), such as economic and environmental factors, are where companies do not have the ability to decide or adjust according to their own discretion or judgment. Such inputs are important to be taken into account from the industrial environment when we evaluate operational efficiency, especially in retail companies.

Initially Charnes, Cooper \& Rhodes (1978) developed DEA to evaluate nonprofit and public sector organizations (Prakash \& Annapoorni, 2015). Afterwards, research using DEA continues to grow rapidly for various sectors, for example in the banking sector (Ohsato \& Takahashi, 2015; Sufian, Kamarudin, \& Nassir, 2016), the college sector (Goksen, Dogan, \& Ozkarabacak, 2015; Ohsato \& Takahashi, 2015), public/ government sector organizations (Zhonghua \& Ye, 2012; Jorge, Carvalho, Jorge, Medeiros, \& Ferreira, 2013; Pang et al., 2013; Buleca \& Mura, 2014; Chitnis \& Mishra, 2019), the hospitality sector (Barros, 2005; Sanjeev, 2007), the aviation sector (Singh, 
2011; Zhu, 2011), the retail sector (Barros, 2005; Yu \& Ramanathan, 2008; Lau, 2013; Ahmad et al., 2014; Ko et al., 2017; Liu et al., 2018; Gong et al., 2019).

\subsection{Operational Performance}

Many researchers in the operations management community are interested in evaluating the performance of retail companies and assessing the impact of improved operations, both on operational performance and on financial performance.

Most retail company performance measurements use a number of financial measures, such as return on investment (ROI), return on asset ROA), or return on capital employed (ROCE) (Panigyrakis \& Theodoridis, 2007). Meanwhile according to Liu et al. (2018), retail company performance can be seen through its level of productivity, such as: inventory turnover ratio, accounts receivable turnover ratio, total assets or current assets turnover ratio, gross margin, and long-term stock returns. Many researchers criticize such performance measurement models, because they fail to measure various dimensions of performance. Explicitly, there is still limited research that considers aspects of the competitive environment and operating strategies in global markets relating to the operating efficiency of retail companies.

In fact, for it is very important for retail company to do environmental analysis both internal and external. It is important to note that retail companies in their operations rely on their supply chains, where they will face strong pressure from various stakeholder groups, such as end customers, industrial customers, suppliers and financial institutions (Hendricks \& Singhal, 2005).

Retail companies operating in various regions will certainly develop diverse business models that are in accordance with the characteristics of consumers in the region. They also must adjust to the diversity of policies, culture, legislation and politics in the area. As a result of the diversity of such treatments, it may produce varying levels of efficiency from each retail company. This is consistent with the statement of Slater \& Narver (1994), that the competitive environment in various regions affects the operational efficiency of retail companies.

Nowadays, globally integrated retail companies operate in a highly competitive market environment. The operations strategy can be carried out by importing governance management from home countries or mimicking the governance management practices of successful local companies. It can help them carry out their responsibilities, make it easier to make relevant decisions so they can be efficient in operations.

Measuring the performance of retail companies is a complex phenomenon (Liu et al., 2018). Researchers often face difficulties in trying to get accurate financial performance measures. The most common problems are information sensitivity and the unavailability of information for the public. However Panigyrakis \& Theodoridis (2007) has measured the business performance of retail companies (supermarkets) in Greece, using two dimensions, financial performance and non-financial performance. Financial performance is measured by four indicator; total sales, growth rate of sales and gross margin and Non-financial performance is measured by three indicators; market share, space productivity and stock age. The findings indicate a positive relationship between market orientation and the performance of retail companies. In other words market orientation is an important determinant of company performance. Market orientation is defined as the company's ability to understand customers, competitors and environmental factors in a sustainable manner that enables them to act according to current market trends.

Meanwhile Johlke \& Iyer's research (2013), regarding the performance of retail companies in the United States proves that employee ambiguity towards customers and external customer mindset sets are related to sales performance. Mertens, Recker, Kummer, Kohlborn, \& Viaene (2016) conducted a research on constructive deviance as a driver of performance in retail companies. The study was conducted on food retail stores operating in Australia. The results prove that constructive deviance that occurs in retail companies can improve organizational performance. Therefore the application 


\section{Competitive Environment Analysis in Global Retail Companies Operation Strategy: A Data Envelopment Analysis (DEA) Based Approach}

of constructive deviance as a strategic tool in retail companies can be considered. Constructive deviance is deviant behavior carried out with positive intentions that aim to provide positive or beneficial results for the organization without harming other parties or violating norms at a higher level.

\section{Research Method}

\subsection{Research Object}

This research focuses on the top ten retail companies operating in the global market, as presented in the table below.

Table 3 Top Ten Global Retail Companies in 2019

\begin{tabular}{clccc}
\hline DMU & \multicolumn{1}{c}{ Company } & Code & Country & Industry \\
\hline 1. & Walmart & WMT & United States & Retail (Groceries) \\
2. & Amazon.com Inc & AMZN & United States & Retail (via Catalogue \& Courier) \\
3. & Carrefour SA & CARR & France & Retail (Groceries) \\
4. & Tesco PLC & TSCO & Great Britain & Retail (Groceries) \\
5. & Costco & COST & United States & Retail (Spesific) \\
6. & Walgreens Boots Alliance Inc & WBA & United States & Retail (Drugs) \\
7. & Kroger Company & KR & United States & Retail (Groceries) \\
8. & Home Depot Inc & HD & United States & Retail (Households) \\
9. & JD.com Inc Adr & JD & China & Retail (via Catalogue \& Courier) \\
10. & Alibaba Group Holdings Ltd ADR & BABA & China & Retail (via Catalogue \& Courier) \\
\hline \multicolumn{4}{r}{ Sources: summarized from https://id.investing.com and other various sources }
\end{tabular}

\subsection{Research Variables and Data Collection}

There are three input variables used in this study, namely: assets, operating costs and number of employees. In addition there are seven output variables used, namely: total revenue, net profit, return on equity (ROE), return on assets (ROA), return on investment (ROI), dividend payout ratio and asset turnover ratio. Data was obtained from financial reports published on the investing.com website. We focus on the financial statements of the top ten retail companies operating in the global market. The operational variables in this research are presented in the table below.

\section{Table 4 Operational Variables}

\begin{tabular}{|c|c|c|c|}
\hline A. Input & Definition & Ref. & Scale \\
\hline Asset & $\begin{array}{l}\text { An asset definition according to IFRS is a source that } \\
\text { is controlled by an entity as a result of a past event } \\
\text { (for example creating itself or buying) and from } \\
\text { future economic benefits (cash inflows and other } \\
\text { assets) expected to flow to the entity. Assets are } \\
\text { measured in United States dollars (USD). }\end{array}$ & {$[1]$} & Ratio \\
\hline Operating cost & $\begin{array}{l}\text { operating costs or operating expenses are all expenses } \\
\text { directly used to produce goods, including general } \\
\text { costs, sales costs, administrative costs, and loan } \\
\text { interest; costs directly related to the production and } \\
\text { distribution of goods. Operating costs are measured in } \\
\text { United States dollars (USD). }\end{array}$ & {$[2 \mathrm{a}, 2 \mathrm{~b}]$} & Ratio \\
\hline Employee & $\begin{array}{l}\text { Employees are the people working in an institution } \\
\text { (office, company, etc.) with a salary (wages). } \\
\text { Employees are measured in units of people. }\end{array}$ & [3] & Ratio \\
\hline \multicolumn{4}{|c|}{ r } \\
\hline Revenue & $\begin{array}{l}\text { According to IFRS revenue is defined as income } \\
\text { arising from the normal activities of an entity and is } \\
\text { often known by different names, such as: sales, }\end{array}$ & [4] & Ratio \\
\hline
\end{tabular}




\begin{tabular}{|c|c|c|c|}
\hline & $\begin{array}{l}\text { turnover, costs, interest, dividends and royalties. } \\
\text { Revenue is measured in United States dollars (USD). }\end{array}$ & & \\
\hline Net profit & $\begin{array}{l}\text { Net Profit is the amount of profit obtained after tax } \\
\text { deduction. Profit is often used as a financial measure. } \\
\text { Net income is measured in United States dollars } \\
\text { (USD). }\end{array}$ & {$[5 a \& 5 b]$} & Ratio \\
\hline ROE & $\begin{array}{l}\text { Return on Equity (ROE) is defined as net income } \\
\text { divided by shareholder equity. ROE shows the ability } \\
\text { to generate a return on investment based on the book } \\
\text { value of the shareholders. ROE is measured in } \\
\text { percentage }(\%) \text {. }\end{array}$ & $\begin{array}{l}{[6 \mathrm{a}, 6 \mathrm{~b},} \\
6 \mathrm{c}, 6 \mathrm{~d} \\
6 \mathrm{e}]\end{array}$ & Ratio \\
\hline ROA & $\begin{array}{l}\text { Return on Assets is defined as net income divided by } \\
\text { total assets. ROA is measured in percent }(\%) \text {. }\end{array}$ & $\begin{array}{l}{[7 \mathrm{a}, 7 \mathrm{~b},} \\
7 \mathrm{c}, 7 \mathrm{~d}]\end{array}$ & Ratio \\
\hline ROI & $\begin{array}{l}\text { Return on Investment (ROI) is defined as net } \\
\text { operating profit divided by average operating assets. } \\
\text { The higher the ROI of a business segment, the greater } \\
\text { the profit generated from each dollar invested in its } \\
\text { assets. ROI is measured in percentage }(\%) \text {. }\end{array}$ & [8] & Ratio \\
\hline $\begin{array}{l}\text { Dividend yield } \\
\text { ratio }\end{array}$ & $\begin{array}{l}\text { Dividend yield ratio is used to measured rate of return } \\
\text { (only in the form of cash dividends) received by the } \\
\text { investor who purchase ordinary stock at the current } \\
\text { market price. Dividend yield ratio is calculated by } \\
\text { dividing the dividend per share with the market price } \\
\text { per share. This ratio is measured in percent }(\%) \text {. }\end{array}$ & [9] & Ratio \\
\hline Asset turnover ratio & $\begin{array}{l}\text { Asset turnover ratio is defined as sales divided by } \\
\text { total assets. This ratio shows how many sales are } \\
\text { generated from each dollar of company assets. This } \\
\text { ratio is measured in percent (\%). }\end{array}$ & $\begin{array}{l}{[10 \mathrm{a}, 10 \mathrm{~b},} \\
10 \mathrm{c}]\end{array}$ & Ratio \\
\hline \multicolumn{4}{|c|}{$\begin{array}{l}\text { Notes: [1] ICAEW, 2008, page 25; [2a \& 2b] KB, 2020; Scarborough \& Cornwall, 2016, page 425; [3] KBBI, 2016; } \\
\text { [4] ICAEW, 2008, page 62; [5a \& 5b] IAI, 2013; ICAEW, } 2008 \text { page 24; [6a, 6b, 6c, 6d, 6e] Horne \& Wachowicz, } \\
\text { 2009, page 150; Ross, Westerfield, Jaffe, \& Jordan, 2018, page 53; Gorrison et al., 2018, page 739; Brealey, Myers, } \\
\& \text { Marcus, 2018, page 95; Brigham \& Houston, 2019, page 119; 77a, 7b, 7c \& 7d] Horne \& Wachowicz, 2009, page } \\
\text { 157; Brealey, Myers, \& Marcus, 2018, page 94; Ross, Westerfield, Jaffe, \& Jordan, 2018, page 53; Brigham \& } \\
\text { Houston, 2019, page 119; [8] Gorrison et al., 2018, page 509; Horne \& Wachowicz, 2009, page 150; [9] Gorrison, } \\
\text { Noreen, \& Brewer, 2018, page e 742; ; 10a, 10b \& 10c] Brealey et al., 2018, page 96; Gorrison et al., 2018, page 735; } \\
\text { Brigham \& Houston, 2019, page 113. }\end{array}$} \\
\hline
\end{tabular}

\subsection{Data Analysis}

Data Envelopment Analysis (DEA) approach is used for data analysis in this reserach. DEA is a linear programming application that compares a number of company units in the same industry. The results of the model solution provide an indication whether a particular company is less productive or inefficient, compared to other units (Taylor III, 2016, p.164). According to Storto (2013), DEA has the advantage as it is able measure multi-variable input and multi-variable output. In this research, Ten retail companies operating in the global market are treated as a decision making unit (DMU).

The formula used to calculate unit efficiency (Ragsdale, 2008, p.103-104; Ragsdale, 2018, p. 107-108) is as follows:

Where:

$$
\text { unit efficiency } i=\frac{\text { Weight of output unit } i}{\text { Weight of input unit } i}=\frac{\sum_{j=1}^{n 0} o_{i j} X_{j}}{\sum_{j=1}^{n I} I_{i j} Y_{j}}
$$

$\mathrm{O}_{\mathrm{ij}}=$ the value of unit $\mathrm{i}$ on output $\mathrm{j}$

$\mathrm{I}_{\mathrm{ij}}=$ the value of unit $\mathrm{i}$ on input $\mathrm{j}$

$X_{j}=$ non-negatif weight assigned to output $j$

$Y_{j}=$ non-negatif weight assigned to input $j$

$\mathrm{n}_{\mathrm{O}}=$ the number of output variables 
$\mathrm{n}_{\mathrm{I}}=$ the number of input variables

Objective function:

$$
M A X: \sum_{j=1}^{n O} O_{i j} X_{j}
$$

Constraint function:

$$
\sum_{j=1}^{n 0} O_{k j} X_{j} \leq \sum_{j=1}^{n I} I_{k j} Y_{j} \quad \text { Where } \mathrm{k}=1
$$

or in other words:

$$
\sum_{j=1}^{n 0} O_{k j} X_{j}-\sum_{j=1}^{n I} I_{k j} Y_{j} \leq 0 \quad \text { Where } \mathrm{k}=1
$$

The weighted input weight for the unit under investigation (unit i) must be equal to 1 (one), then:

$$
\sum_{j=1}^{n I} I_{i j} Y_{j}=1
$$

To provide accurate results, in solving this problem we use the parameter solver tool available in Microsoft Excel. Macro facilities found in Excel were also used so that the calculation can be conducted simultaneously. The efficiency score of a DMU must be less than or equal to one $(\leq 1.00)$. If the score isequal to one $(=1.00)$, then the DMU is said to be 'efficient', or has 'good performance'. Whereas if the score of DMU is less than one $(<1.00)$, then the DMU is said to be 'inefficient', or has 'poor performance'.

\section{Results}

This research uses three input variables, namely: total assets, total operating costs and number of employees. In addition, there are seven output variables used, namely: total revenue, net profit, ROE, ROA, ROI, dividend payout ratio and asset turnover ratio. Data of input variables and output variables used in the analysis are presented in the table below.

\begin{tabular}{|c|c|c|c|c|c|c|c|c|c|}
\hline \multirow[b]{2}{*}{ DMU } & \multirow[b]{2}{*}{ Company } & \multicolumn{7}{|c|}{ Output } & \multirow[b]{2}{*}{ Ref. } \\
\hline & & $\begin{array}{c}\text { Revenue } \\
\text { (Million } \\
\text { USD) }\end{array}$ & $\begin{array}{c}\text { Net } \\
\text { Profit } \\
\text { (Million } \\
\text { USD) }\end{array}$ & $\begin{array}{c}\text { ROE } \\
(\%)\end{array}$ & $\begin{array}{c}\text { ROA } \\
(\%)\end{array}$ & $\begin{array}{l}\text { ROI } \\
(\%)\end{array}$ & $\begin{array}{c}\text { Dividend } \\
\text { yield } \\
(\%)\end{array}$ & $\begin{array}{c}\text { Asset } \\
\text { Turnover } \\
\text { (\%) }\end{array}$ & \\
\hline 1. & Walmart & 127,991 & 3,288 & 20.22 & 6.67 & 10.61 & 1.68 & 2.30 & [1] \\
\hline 2. & Amazon.com Inc & 87,436 & 3,268 & 21.95 & 5.98 & 10.01 & 17.20 & 1.45 & [2] \\
\hline 3. & Carrefour SA & 41,611 & 1,719 & 0.33 & 0.44 & 0.91 & 3.26 & 1.51 & [3] \\
\hline 4. & Tesco PLC & 39,864 & 405 & 9.71 & 2.28 & 3.65 & 3.93 & 1.12 & [4] \\
\hline
\end{tabular}

Table 5 Input Variable Data Used in the Analysis, 2019

\begin{tabular}{clcccc}
\hline \multirow{2}{*}{ DMUU } & \multicolumn{1}{c}{ Company } & $\begin{array}{c}\text { Input } \\
\text { Asset (Million USD) }\end{array}$ & $\begin{array}{c}\text { Ref. } \\
\text { Operational Cost (Million USD) }\end{array}$ & Employees (Person) & \\
\hline 1. & Walmart & 239,830 & 136,349 & $2,200,000$ & {$[1]$} \\
2. & Amazon.com Inc & 225,248 & 83,557 & 798,000 & {$[2]$} \\
3. & Carrefour SA & 55,064 & 40,475 & 321,383 & {$[3]$} \\
4. & Tesco PLC & 70,758 & 38,447 & 464,505 & {$[4]$} \\
5. & Costco & 51,431 & 35,979 & 149,000 & {$[5]$} \\
6. & Walgreens Boots Alliance Inc & 90,807 & 34,339 & 232,000 & {$[6]$} \\
7. & Kroger Company & 45,393 & 27,720 & 435,000 & {$[7]$} \\
8. & Home Depot Inc & 52,309 & 23,276 & 415,700 & {$[8]$} \\
9. & JD.com Inc Adr & 36,725 & 24,060 & 178,927 & {$[9]$} \\
10. & Alibaba Group Holdings Ltd ADR & 186,577 & 17,236 & 116,519 & {$[10]$} \\
\hline \hline
\end{tabular}

Table 6 Output Variable Data used in the Analysis, 2019 


\begin{tabular}{|c|c|c|c|c|c|c|c|c|c|}
\hline 5. & Costco & 37,040 & 844 & 24.59 & 8.29 & 16.61 & 0.84 & 3.46 & {$[5]$} \\
\hline 6. & Walgreens Boots Alliance Inc & 34,339 & 844 & 14.41 & 4.38 & 6.67 & 4.21 & 1.73 & [6] \\
\hline 7. & Kroger Company & 27,974 & 263 & 19.91 & 3.63 & 5.50 & 2.00 & 2.93 & [7] \\
\hline 8. & Home Depot Inc & 27,223 & 2,769 & 79.26 & 23.61 & 37.38 & 3.02 & 2.31 & [8] \\
\hline 9. & JD.com Inc Adr & 24,135 & 514 & 17.21 & 5.07 & 13.81 & 17.20 & 2.46 & [9] \\
\hline 10. & Alibaba Group Holdings Ltd ADR & 22,830 & 7,397 & 28.54 & 15.36 & 22.16 & 17.20 & 0.44 & [10] \\
\hline
\end{tabular}

Notes: the data sources listed in table 5 and table 6 above are [1] Investing.com, 2020j; [2] Investing.com, 2020b; [3] Investing.com, 2020c; [4] Investing.com, 2020h; [5] Investing.com, 2020d; [6] Investing.com, 2020g; [7] Investing.com, 2020g; [8] Investing.com, 2020e; [9] Investing.com, 2020f; [10] Investing.com, 2020a.

For information, some of the companies in this research presented their financial report in different currencies other than United States Dollar (USD) . Tesco PLC presented their financial report in Great Britain Pound (GBP), Carrefour SA uses Euro (EUR), JD.com Inc. Adr and Alibaba Group Holdings Ltd. ADR uses Chinese Yuan $(\mathrm{CNY})$. Therefore, for uniformity we converted the currencies into United States dollars (USD) using a currency converter (investing.com, 2020e). By using this tool, currency conversion can be done retroactively in accordance with the date of the company's financial statements, which are at the end of 2019.

To evaluate the efficiency of retail companies from unit 1 to unit 10, we formulated a linear DEA program with the implementation of the model as follows:

\section{DMU 1: Walmart}

Max: $\quad 127,991_{\mathrm{x} 1}+3,288_{\mathrm{x} 2}+20.22_{\mathrm{x} 3}+6.67_{\mathrm{x} 4}+10.61_{\mathrm{x} 5}+1.68_{\mathrm{x} 6}+2.3_{\mathrm{x} 7}$

Subject to: $\quad 127,991_{\mathrm{x} 1}+3,288_{\mathrm{x} 2}+20.22_{\mathrm{x} 3}+6.67_{\mathrm{x} 4}+10.61_{\mathrm{x} 5}+1.68_{\mathrm{x} 6}+2.30_{\mathrm{x} 7}-$ $239,830_{\mathrm{y} 1}-136,349_{\mathrm{y} 2}-2,200,000_{\mathrm{y} 3} \leq 0$

constrain

for unit 1

$87,436_{\mathrm{x} 1}+3,268_{\mathrm{x} 2}+21.95_{\mathrm{x} 3}+5.98_{\mathrm{x} 4}+10.01_{\mathrm{x} 5}+17.20_{\mathrm{x} 6}+1.45_{\mathrm{x} 7}-$

constrain

$225,248_{\mathrm{y} 1}-83,557_{\mathrm{y} 2}-798,000_{\mathrm{y} 3} \leq 0$

for unit 2

and so on to ...

$22,830_{\mathrm{x} 1}+7,397_{\mathrm{x} 2}+28.54_{\mathrm{x} 3}+15.36_{\mathrm{x} 4}+22.16_{\mathrm{x} 5}+17.20_{\mathrm{x} 6}+0.44_{\mathrm{x} 7}-$

constrain $186,577_{\mathrm{y} 1}-17,236_{\mathrm{y} 2}-116,519_{\mathrm{y} 3} \leq 0$

for unit 10

$$
239,830_{\mathrm{y} 1}+136,349_{\mathrm{y} 2}+2,200,000_{\mathrm{y} 3}=1
$$

input constrain

for unit 1

$$
x 1, x 2, x 3, x 4, x 5, x 6, x 7, y 1, y 2, y 3 \geq 0
$$

nonnegativity conditions

\section{DMU 2: Amazon.com}

$$
\begin{array}{llr}
\text { Max: } & 87,436_{\mathrm{x} 1}+3,268_{\mathrm{x} 2}+21.95_{\mathrm{x} 3}+5.98_{\mathrm{x} 4}+10.01_{\mathrm{x} 5}+17.20_{\mathrm{x} 6}+1.45_{\mathrm{x} 7} & \\
\text { Subject to: } & 127,991_{\mathrm{x} 1}+3,288_{\mathrm{x} 2}+20.22_{\mathrm{x} 3}+6.67_{\mathrm{x} 4}+10.61_{\mathrm{x} 5}+1.68_{\mathrm{x} 6}+2.30_{\mathrm{x} 7}- & \text { constrain } \\
239,830_{\mathrm{y} 1}-136,349_{\mathrm{y} 2}-2,200,000_{\mathrm{y} 3} \leq 0 & \text { for unit } 1 \\
& 87,436_{\mathrm{x} 1}+3,268_{\mathrm{x} 2}+21.95_{\mathrm{x} 3}+5.98_{\mathrm{x} 4}+10.01_{\mathrm{x} 5}+17.20_{\mathrm{x} 6}+1.45_{\mathrm{x} 7}- & \text { constrain } \\
225,248_{\mathrm{y} 1}-83,557_{\mathrm{y} 2}-798,000_{\mathrm{y} 3} \leq 0 & \text { for unit } 2 \\
& \text { and } \text { So on to } \ldots & \text { constrain } \\
22,830_{\mathrm{x} 1}+7,397_{\mathrm{x} 2}+28.544_{\mathrm{x} 3}+15.36_{\mathrm{x} 4}+22.16_{\mathrm{x} 5}+17.20_{\mathrm{x} 6}+0.44_{\mathrm{x} 7}- & \text { for unit 10 } \\
186,577_{\mathrm{y} 1}-17,236_{\mathrm{y} 2}-116,519_{\mathrm{y} 3} \leq 0 & \text { input constrain }
\end{array}
$$


Competitive Environment Analysis in Global Retail Companies Operation Strategy: A

Data Envelopment Analysis (DEA) Based Approach

for unit 2

$x 1, x 2, x 3, x 4, x 5, x 6, x 7, y 1, y 2, y 3 \geq 0$

nonnegativity conditions

\section{DMU 3: Carrefour SA}

Max: $\quad 41,611_{\mathrm{x} 1}+1,719_{\mathrm{x} 2}+0.33_{\mathrm{x} 3}+0.44_{\mathrm{x} 4}+0.91_{\mathrm{x} 5}+3.26_{\mathrm{x} 6}+1.51_{\mathrm{x} 7}$

Subject to: $\quad 127,991_{\mathrm{x} 1}+3,288_{\mathrm{x} 2}+20.22_{\mathrm{x} 3}+6.67_{\mathrm{x} 4}+10.61_{\mathrm{x} 5}+1.68_{\mathrm{x} 6}+2.30_{\mathrm{x} 7}-$ $239,830_{\mathrm{y} 1}-136,349_{\mathrm{y} 2}-2,200,000_{\mathrm{y} 3} \leq 0$

constrain

for unit 1

$87,436_{\mathrm{x} 1}+3,268_{\mathrm{x} 2}+21.95_{\mathrm{x} 3}+5.98_{\mathrm{x} 4}+10.01_{\mathrm{x} 5}+17.20_{\mathrm{x} 6}+1.45_{\mathrm{x} 7}-$

constrain

$225,248_{\mathrm{y} 1}-83,557_{\mathrm{y} 2}-798,000_{\mathrm{y} 3} \leq 0$

for unit 2

and so on to ...

$22,830_{\mathrm{x} 1}+7,397_{\mathrm{x} 2}+28.54_{\mathrm{x} 3}+15.36_{\mathrm{x} 4}+22.16_{\mathrm{x} 5}+17.20_{\mathrm{x} 6}+0.44_{\mathrm{x} 7}-$ $186,577_{\mathrm{y} 1}-17,236_{\mathrm{y} 2}-116,519_{\mathrm{y} 3} \leq 0$

constrain for unit 10

$$
55,064_{\mathrm{y} 1}+40,475_{\mathrm{y} 2}+321,383_{\mathrm{y} 3}=1
$$

input constrain

for unit 3

$x 1, x 2, x 3, x 4, x 5, x 6, x 7, y 1, y 2, y 3 \geq 0$

nonnegativity conditions

\section{DMU 4: Tesco PLC}

Max: $\quad 39,864_{\mathrm{x} 1}+405_{\mathrm{x} 2}+9.71_{\mathrm{x} 3}+2.28_{\mathrm{x} 4}+3.65_{\mathrm{x} 5}+3.93_{\mathrm{x} 6}+1.12_{\mathrm{x} 6}$

Subject to: $\quad 127,991_{\mathrm{x} 1}+3,288_{\mathrm{x} 2}+20.22_{\mathrm{x} 3}+6.67_{\mathrm{x} 4}+10.61_{\mathrm{x} 5}+1.68_{\mathrm{x} 6}+2.30_{\mathrm{x} 7}-$

constrain $239,830_{\mathrm{y} 1}-136,349_{\mathrm{y} 2}-2,200,000_{\mathrm{y} 3} \leq 0$

for unit 1

$87,436_{\mathrm{x} 1}+3,268_{\mathrm{x} 2}+21.95_{\mathrm{x} 3}+5.98_{\mathrm{x} 4}+10.01_{\mathrm{x} 5}+17.20_{\mathrm{x} 6}+1.45_{\mathrm{x} 7}-$ constrain $225,248_{\mathrm{y} 1}-83,557_{\mathrm{y} 2}-798,000_{\mathrm{y} 3} \leq 0$

for unit 2

and so on to ...

$22,830_{\mathrm{x} 1}+7,397_{\mathrm{x} 2}+28.54_{\mathrm{x} 3}+15.36_{\mathrm{x} 4}+22.16_{\mathrm{x} 5}+17.20_{\mathrm{x} 6}+0.44_{\mathrm{x} 7}-$

constrain $186,577_{\mathrm{y} 1}-17,236_{\mathrm{y} 2}-116,519_{\mathrm{y} 3} \leq 0$ for unit 10

$$
70,758_{\mathrm{y} 1}+38,447_{\mathrm{y} 2}+464,505_{\mathrm{y} 3}=1
$$

input constrain

for unit 4

$$
x 1, x 2, x 3, x 4, x 5, x 6, x 7, y 1, y 2, y 3 \geq 0
$$

nonnegativity conditions

\section{DMU 5: Costco}

Max: $\quad 37,040_{\mathrm{x} 1}+844_{\mathrm{x} 2}+24.59_{\mathrm{x} 3}+8.29_{\mathrm{x} 4}+16.61_{\mathrm{x} 5}+0.84_{\mathrm{x} 6}+3.46_{\mathrm{x} 7}$

Subject to: $\quad 127,991_{\mathrm{x} 1}+3,288_{\mathrm{x} 2}+20.22_{\mathrm{x} 3}+6.67_{\mathrm{x} 4}+10.61_{\mathrm{x} 5}+1.68_{\mathrm{x} 6}+2.30_{\mathrm{x} 7}-$ $239,830_{\mathrm{y} 1}-136,349_{\mathrm{y} 2}-2,200,000_{\mathrm{y} 3} \leq 0$

constrain for unit 1

$87,436_{\mathrm{x} 1}+3,268_{\mathrm{x} 2}+21.95_{\mathrm{x} 3}+5.98_{\mathrm{x} 4}+10.01_{\mathrm{x} 5}+17.20_{\mathrm{x} 6}+1.45_{\mathrm{x} 7}-$ constrain $225,248_{\mathrm{y} 1}-83,557_{\mathrm{y} 2}-798,000_{\mathrm{y} 3} \leq 0$ for unit 2

and so on to ...

$22,830_{\mathrm{x} 1}+7,397_{\mathrm{x} 2}+28.54_{\mathrm{x} 3}+15.36_{\mathrm{x} 4}+22.16_{\mathrm{x} 5}+17.20_{\mathrm{x} 6}+0.44_{\mathrm{x} 7}-$ $186,577_{\mathrm{y} 1}-17,236_{\mathrm{y} 2}-116,519_{\mathrm{y} 3} \leq 0$ 


$$
\begin{aligned}
& 51,431_{\mathrm{y} 1}+35,979_{\mathrm{y} 2}+149,000_{\mathrm{y} 3}=1 \\
& \mathrm{x} 1, \mathrm{x} 2, \mathrm{x} 3, \mathrm{x} 4, \mathrm{x} 5, \mathrm{x} 6, \mathrm{x} 7, \mathrm{y} 1, \mathrm{y} 2, \mathrm{y} 3 \geq 0
\end{aligned}
$$

input constrain for unit 5

nonnegativity conditions

DMU 6: Walgreens Boots Alliance Inc

Max: $\quad 34,339_{\mathrm{x} 1}+844_{\mathrm{x} 2}+14.41_{\mathrm{x} 3}+4.38_{\mathrm{x} 4}+6.67_{\mathrm{x} 5}+4.21_{\mathrm{x} 6}+1.73_{\mathrm{x} 7}$

Subject to: $\quad 127,991_{\mathrm{x} 1}+3,288_{\mathrm{x} 2}+20.22_{\mathrm{x} 3}+6.67_{\mathrm{x} 4}+10.61_{\mathrm{x} 5}+1.68_{\mathrm{x} 6}+2.30_{\mathrm{x} 7}-$ constrain $239,830_{\mathrm{y} 1}-136,349_{\mathrm{y} 2}-2,200,000_{\mathrm{y} 3} \leq 0$ for unit 1

$87,436_{\mathrm{x} 1}+3,268_{\mathrm{x} 2}+21.95_{\mathrm{x} 3}+5.98_{\mathrm{x} 4}+10.01_{\mathrm{x} 5}+17.20_{\mathrm{x} 6}+1.45_{\mathrm{x} 7}-$ constrain $225,248_{\mathrm{y} 1}-83,557_{\mathrm{y} 2}-798,000_{\mathrm{y} 3} \leq 0$ for unit 2

and so on to ...

$22,830_{\mathrm{x} 1}+7,397_{\mathrm{x} 2}+28.54_{\mathrm{x} 3}+15.36_{\mathrm{x} 4}+22.16_{\mathrm{x} 5}+17.20_{\mathrm{x} 6}+0.44_{\mathrm{x} 7}-$ $186,577_{\mathrm{y} 1}-17,236_{\mathrm{y} 2}-116,519_{\mathrm{y} 3} \leq 0$ constrain for unit 10

$$
90,807_{\mathrm{y} 1}+34,339_{\mathrm{y} 2}+232,000_{\mathrm{y} 3}=1
$$

input constrain for unit 6 $x 1, x 2, x 3, x 4, x 5, x 6, x 7, y 1, y 2, y 3 \geq 0$ nonnegativity conditions

\section{DMU 7: Kroger Company}

Max: $\quad 27,974_{\mathrm{x} 1}+263_{\mathrm{x} 2}+19.91_{\mathrm{x} 3}+3.63_{\mathrm{x} 4}+5.50_{\mathrm{x} 5}+2.00_{\mathrm{x} 6}+2.93_{\mathrm{x} 7}$

Subject to: $\quad 127,991_{\mathrm{x} 1}+3,288_{\mathrm{x} 2}+20.22_{\mathrm{x} 3}+6.67_{\mathrm{x} 4}+10.61_{\mathrm{x} 5}+1.68_{\mathrm{x} 6}+2.30_{\mathrm{x} 7}-$ constrain $239,830_{\mathrm{y} 1}-136,349_{\mathrm{y} 2}-2,200,000_{\mathrm{y} 3} \leq 0$ for unit 1

$87,436_{\mathrm{x} 1}+3,268_{\mathrm{x} 2}+21.95_{\mathrm{x} 3}+5.98_{\mathrm{x} 4}+10.01_{\mathrm{x} 5}+17.20_{\mathrm{x} 6}+1.45_{\mathrm{x} 7}-$ constrain $225,248_{\mathrm{y} 1}-83,557_{\mathrm{y} 2}-798,000_{\mathrm{y} 3} \leq 0$ for unit 2

and so on to ...

$22,830_{\mathrm{x} 1}+7,397_{\mathrm{x} 2}+28.54_{\mathrm{x} 3}+15.36_{\mathrm{x} 4}+22.16_{\mathrm{x} 5}+17.20_{\mathrm{x} 6}+0.44_{\mathrm{x} 7}-$ $186,577_{\mathrm{y} 1}-17,236_{\mathrm{y} 2}-116,519_{\mathrm{y} 3} \leq 0$

constrain for unit 10

$$
45,393_{\mathrm{y} 1}+27,720_{\mathrm{y} 2}+435,000_{\mathrm{y} 3}=1
$$
input constrain for unit 7

$$
x 1, x 2, x 3, x 4, x 5, x 6, x 7, y 1, y 2, y 3 \geq 0
$$

nonnegativity conditions

\section{DMU 8: Home Depot Inc}

Max: $\quad 27,223_{\mathrm{x} 1}+2,769_{\mathrm{x} 2}+79.26_{\mathrm{x} 3}+23.61_{\mathrm{x} 4}+37.38_{\mathrm{x} 5}+3.02_{\mathrm{x} 6}+2.31_{\mathrm{x} 7}$

Subject to: $\quad 127,991_{\mathrm{x} 1}+3,288_{\mathrm{x} 2}+20.22_{\mathrm{x} 3}+6.67_{\mathrm{x} 4}+10.61_{\mathrm{x} 5}+1.68_{\mathrm{x} 6}+2.30_{\mathrm{x} 7}-$ $239,830_{\mathrm{y} 1}-136,349_{\mathrm{y} 2}-2,200,000_{\mathrm{y} 3} \leq 0$

constrain for unit 1

$87,436_{\mathrm{x} 1}+3,268_{\mathrm{x} 2}+21.95_{\mathrm{x} 3}+5.98_{\mathrm{x} 4}+10.01_{\mathrm{x} 5}+17.20_{\mathrm{x} 6}+1.45_{\mathrm{x} 7}-$ constrain $225,248_{\mathrm{y} 1}-83,557_{\mathrm{y} 2}-798,000_{\mathrm{y} 3} \leq 0$ for unit 2

and so on to ... 
Competitive Environment Analysis in Global Retail Companies Operation Strategy: A

Data Envelopment Analysis (DEA) Based Approach

$$
\begin{array}{cr}
22,830_{\mathrm{x} 1}+7,397_{\mathrm{x} 2}+28.54_{\mathrm{x} 3}+15.36_{\mathrm{x} 4}+22.16_{\mathrm{x} 5}+17.20_{\mathrm{x} 6}+0.44_{\mathrm{x} 7}- & \text { constrain } \\
186,577_{\mathrm{y} 1}-17,236_{\mathrm{y} 2}-116,519_{\mathrm{y} 3} \leq 0 & \text { for unit } 10 \\
52,309_{\mathrm{y} 1}+23,276_{\mathrm{y} 2}+415,700_{\mathrm{y} 3}=1 & \text { input constrain } \\
\mathrm{x} 1, \mathrm{x} 2, \mathrm{x} 3, \mathrm{x} 4, \mathrm{x} 5, \mathrm{x} 6, \mathrm{x} 7, \mathrm{y} 1, \mathrm{y} 2, \mathrm{y} 3 \geq 0 & \text { for unit } 8 \\
& \text { nonnegativity conditions }
\end{array}
$$

\section{DMU 9: JD.com Inc Adr}

Max: $\quad 24.135_{\mathrm{x} 1}+514_{\mathrm{x} 2}+17,21_{\mathrm{x} 3}+5,07_{\mathrm{x} 4}+13,81_{\mathrm{x} 5}+17,20_{\mathrm{x} 6}+2,46_{\mathrm{x} 7}$

Subject to: $\quad 127.991_{\mathrm{x} 1}+3.288_{\mathrm{x} 2}+20,22_{\mathrm{x} 3}+6,67_{\mathrm{x} 4}+10,61_{\mathrm{x} 5}+1,68_{\mathrm{x} 6}+2,30_{\mathrm{x} 7}-$

constrain

$239.830_{\mathrm{y} 1}-136.349_{\mathrm{y} 2}-2.200 .000_{\mathrm{y} 3} \leq 0$

for unit 1

$87.436_{\mathrm{x} 1}+3.268_{\mathrm{x} 2}+21,95_{\mathrm{x} 3}+5,98_{\mathrm{x} 4}+10,01_{\mathrm{x} 5}+17,20_{\mathrm{x} 6}+1,45_{\mathrm{x} 7}-$

constrain

$225.248_{\mathrm{y} 1}-83.557_{\mathrm{y} 2}-798.000_{\mathrm{y} 3} \leq 0$

for unit 2

and so on to ...

$\begin{array}{lr}22.830 \mathrm{x} 1+7.397 \mathrm{x} 2+28,54 \mathrm{x} 3+15,36 \mathrm{x} 4+22,16 \mathrm{x} 5+17,20 \mathrm{x} 6 & \text { constrain } \\ +0,44 \mathrm{x} 7-186.577 \mathrm{y} 1-17.236 \mathrm{y} 2-116.519 \mathrm{y} 3 \leq 0 & \text { for unit } 10\end{array}$

$$
36.725 y 1+24.060 y 2+178.927 y 3=1
$$

input constrain

for unit 9

$$
\mathrm{x} 1, \mathrm{x} 2, \mathrm{x} 3, \mathrm{x} 4, \mathrm{x} 5, \mathrm{x} 6, \mathrm{x} 7, \mathrm{y} 1, \mathrm{y} 2, \mathrm{y} 3 \geq 0 \quad \text { nonnegativity conditions }
$$

\section{DMU 10: Alibaba Group Holdings Ltd ADR}

Max:

$$
22,830_{x 1}+7,397_{x 2}+28.54_{x 3}+15.36_{x 4}+22.16_{x 5}+17.20_{x 6}+0.44_{x 7}
$$

Subject to: $\quad 127,991_{\mathrm{x} 1}+3,288_{\mathrm{x} 2}+20.22_{\mathrm{x} 3}+6.67_{\mathrm{x} 4}+10.61_{\mathrm{x} 5}+1.68_{\mathrm{x} 6}+2.30_{\mathrm{x} 7}-$

constrain $239,830_{\mathrm{y} 1}-136,349_{\mathrm{y} 2}-2,200,000_{\mathrm{y} 3} \leq 0$

for unit 1

$87,436_{\mathrm{x} 1}+3,268_{\mathrm{x} 2}+21.95_{\mathrm{x} 3}+5.98_{\mathrm{x} 4}+10.01_{\mathrm{x} 5}+17.20_{\mathrm{x} 6}+1.45_{\mathrm{x} 7}-$

constrain $225,248_{\mathrm{y} 1}-83,557_{\mathrm{y} 2}-798,000_{\mathrm{y} 3} \leq 0$

for unit 2

and so on to ...

$$
\begin{array}{cr}
22,830_{\mathrm{x} 1}+7,397_{\mathrm{x} 2}+28.54_{\mathrm{x} 3}+15.36_{\mathrm{x} 4}+22.16_{\mathrm{x} 5}+17.20_{\mathrm{x} 6}+0.44_{\mathrm{x} 7}- & \text { constrain } \\
186,577_{\mathrm{y} 1}-17,236_{\mathrm{y} 2}-116,519_{\mathrm{y} 3} \leq 0 & \text { for unit } 10 \\
186,577_{\mathrm{y} 1}+17,236_{\mathrm{y} 2}+116,519_{\mathrm{y} 3}=1 & \text { input constrain } \\
& \text { for unit } 10
\end{array}
$$

$$
x 1, x 2, x 3, x 4, x 5, x 6, x 7, y 1, y 2, y 3 \geq 0
$$

nonnegativity conditions

To solve this complex problem, we used parameter solver tool and macro facilities found in Microsoft Excel for data processing. The results of data processing as shown in the table below. 
Table 7 Global Retail Company Efficiency Score data, 2019

\begin{tabular}{clcc}
\hline DMU & \multicolumn{1}{c}{ Company } & Efficiency Score & Conclusion \\
\hline 1. & Walmart & 0.86 & Inefficient \\
2. & Amazon.com Inc & 0.94 & Inefficient \\
3. & Carrefour SA & 1.00 & Efficient \\
4. & Tesco PLC & 0.94 & Inefficient \\
5. & Costco & 1.00 & Efficient \\
6. & Walgreens Boots Alliance Inc & 0.92 & Inefficient \\
7. & Kroger Company & 1.00 & Efficient \\
8. & Home Depot Inc & 1.00 & Efficient \\
9. & JD.com Inc Adr & 1.00 & Efficient \\
10. & Alibaba Group Holdings Ltd ADR & 1.00 & Efficient \\
\hline \hline
\end{tabular}

Source: DEA result

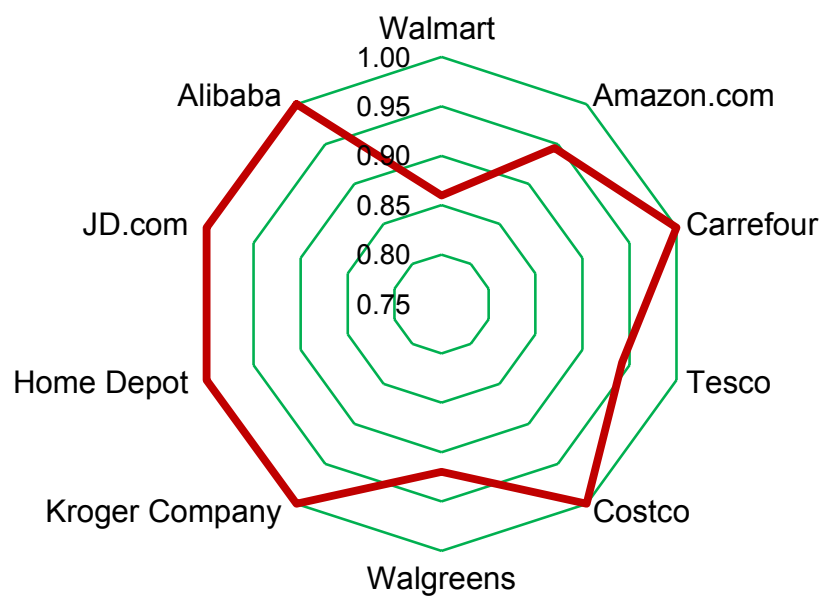

Figure 1 Radar Chart of Global Retail Companies efficiency

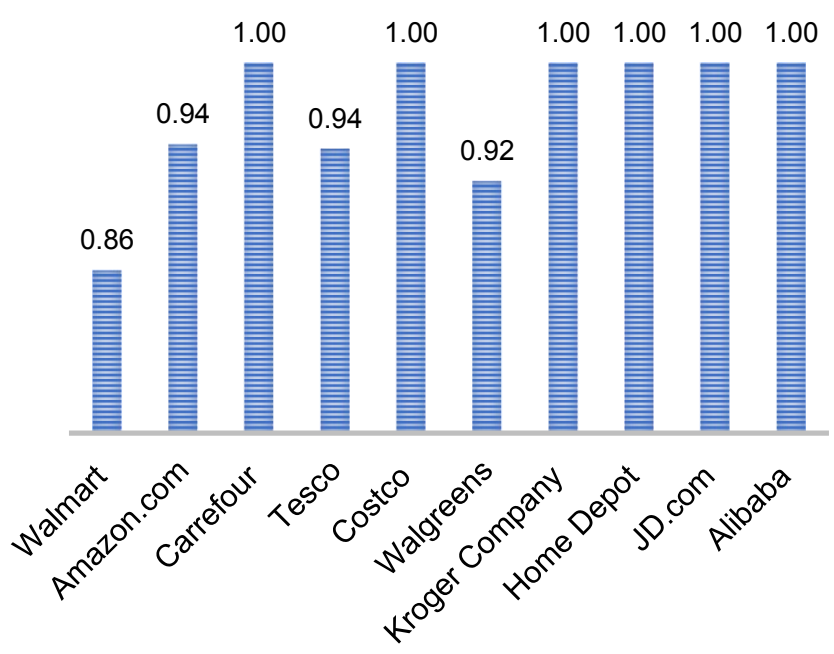

Figure 2 Bar Chart of Global Retail Companies efficiency

\section{Discussion}

Based on table 7 above, we obtained the information that from the top ten (top ten) retail companies operating in the global market, there are six companies that are efficient in carrying out their operations, thus the companies are considered to be the most competitive company in the global market, They are: Carrefour, Costco, Kroger Company, Home Depot Inc., JD.com and Alibaba Group Holdings Ltd. While the remaining four companies, namely: Walmart, Amazon.com, Tesco and Walgreens Boots Alliance are considered to be inefficient in conducting operations in the global market. Thus it can be concluded that the companies are less competitive.

Although retail companies such as Walmart has the largest total revenue and Amazon.com has the second largest total revenue, the results of the model solutions show that they are inefficient. That is because they are unable to utilize available abundant input resources to produce maximum output.

Below we outline the DEA's suggestions for these inefficient retail companies to be more competitive in the global market environment, which can be seen from the composite value and sensitivity report. 
Competitive Environment Analysis in Global Retail Companies Operation Strategy: A

Data Envelopment Analysis (DEA) Based Approach

Table 8 Inefficient Global Retail Company, 2019

\begin{tabular}{clcc}
\hline DMU & \multicolumn{1}{c}{ Company } & Efficiency Score & Conclusion \\
\hline 1. & Walmart & 0.86 & Inefficient \\
2. & Amazon.com Inc & 0.94 & Inefficient \\
4. & Tesco PLC & 0.94 & Inefficient \\
6. & Walgreens Boots Alliance Inc & 0.92 & Inefficient \\
\hline \hline
\end{tabular}

Based on the composite value, to achieve high level of performance (efficiency score 1.00), for Walmart, Amazon.com Inc., Tesco PLC and Walgreens Boots Alliance Inc., it is recommended to decrease the number of inputs and increase a certain number of outputs, sequentially shown below this.

DMU 1: Walmart

\begin{tabular}{|c|c|c|c|}
\hline Input & Initial & Final & $\begin{array}{l}\text { Increase } \\
\text { (Decrease) }\end{array}$ \\
\hline Asset (Million USD) & 239,830 & 206,28 & $(33,602)$ \\
\hline Operational Cost (Million USD) & 136,349 & 117,246 & $(19,103)$ \\
\hline Employees & $2,200,000$ & $1,453,520$ & $(746,480)$ \\
\hline Output & Initial & Final & $\begin{array}{l}\text { Increase } \\
\text { (Decrease) }\end{array}$ \\
\hline Revenue (Million USD) & 127,991 & 127,991 & 0 \\
\hline Net Profit (Milliom USD) & 3,288 & 9,010 & 5,722 \\
\hline $\mathrm{ROE}(\%)$ & 20.22 & 179.92 & 159.70 \\
\hline ROA (\%) & 6.67 & 54.14 & 47.47 \\
\hline ROI (\%) & 10.61 & 86.05 & 75.44 \\
\hline Dividend Yield (\%) & 1.68 & 12.04 & 10.36 \\
\hline Asset Turnover (\%) & 2.30 & 7.64 & 5.34 \\
\hline
\end{tabular}

DMU 2: Amazon.com Inc

\begin{tabular}{lrrr}
\hline \multicolumn{1}{c}{ Input } & Initial & Final & \multicolumn{1}{c}{$\begin{array}{c}\text { Increase } \\
\text { (Decrease) }\end{array}$} \\
\hline Asset (Million USD) & 225,248 & 212,830 & $(12,418)$ \\
Operational cost (Million USD) & 83,557 & 78,951 & $(4,606)$ \\
Employees & 798,000 & 754,007 & $(43,993)$ \\
\hline \multicolumn{1}{c}{ Output } & & & \\
\hline & Initial & Final & Increase \\
(Decrease)
\end{tabular}


DMU 4: Tesco PLC

\begin{tabular}{lrrr}
\hline \multicolumn{1}{c}{ Input } & \multicolumn{1}{c}{ Initial } & \multicolumn{1}{c}{ Final } & \multicolumn{1}{c}{$\begin{array}{c}\text { Increase } \\
\text { (Decrease) }\end{array}$} \\
\hline Asset (Million USD) & 70,758 & 66,647 & $(4,111)$ \\
Operational cost (Million USD) & 38,447 & 36,213 & $(2,234)$ \\
Employees & 464,505 & 437,516 & $(26,989)$ \\
\hline \multicolumn{1}{c}{ Output } & & & \\
\hline & Initial & Final & Increase \\
& & & (Decrease) \\
\hline Revenue (Million USD) & 39,864 & 39,864 & 0 \\
Net Profit (Million USD) & 405 & 2,772 & 2,368 \\
ROE (\%) & 9.71 & 70.72 & 61.01 \\
ROA (\%) & 2.28 & 21.37 & 19.09 \\
ROI (\%) & 3.65 & 35.01 & 31.36 \\
Dividend Yield (\%) & 3.93 & 3.93 & 0.00 \\
Asset Turnover (\%) & 1.12 & 3.11 & 1.99 \\
\hline
\end{tabular}

DMU 6: Walgreens Boots Alliance Inc

\begin{tabular}{lrrr}
\hline \multicolumn{1}{c}{ Input } & Initial & Final & $\begin{array}{c}\text { Increase } \\
\text { (Decrease) }\end{array}$ \\
\hline Asset (Million USD) & 90,807 & 83,543 & $(7,264)$ \\
Operational cost (Million USD) & 34,339 & 31,592 & $\begin{array}{r}(2,747) \\
\text { Employees }\end{array}$ \\
\hline \multicolumn{1}{c}{ Output } & 232,000 & 213,442 & $(18,558)$ \\
\hline & Initial & Final & \multicolumn{1}{c}{ Increase } \\
(Decrease)
\end{tabular}

Based on the sensitivity report, for Walmart, Amazon.com, Tesco and Walgreens Boots Alliance to be "efficient", It is suggested for these companies to increase their output. There are two options available for Walmart. They are either increasing output by $159.52 \%$ when referring to DMU 3 (Carrefour), or by $226.33 \%$ when referring to DMU 8 (Home Depot). For Amazon.com there are four options available. They are either to increase output by $101.04 \%$ when referring to DMU 5 (Costco), or by $120.43 \%$ when referring to DMU 8 (Home Depot), or by $26.73 \%$ when referring to DMU 9 (JD.com), or by $47.19 \%$ when referring to DMU 10 (Alibaba.com).

In addition, Tesco has four options available. They are either increasing output by $18.10 \%$ when referring to DMU 3 (Carrefour), or by $25.61 \%$ when referring to DMU 5 (Costco), or by $80.33 \%$ when referring to DMU 8 (Home Depot), or by $4.06 \%$ when referring to DMU 9 (JD.com). For Walgreens Boots Alliance there are three options available. They are either to increase output by $63.93 \%$ when referring to DMU 5 
Competitive Environment Analysis in Global Retail Companies Operation Strategy: A Data Envelopment Analysis (DEA) Based Approach

(Costco), or by $22.90 \%$ when referring to DMU 8 (Home Depot), or by $21.01 \%$ when referring to on DMU 10 (Alibaba.com).

\section{Conclusion}

The analysis results shows that from top ten global retail companies operating in current global market, six retail companies are "efficient" in its operation (efficiency score of 1.00), Namely: Carrefour, Costco, Kroger Company, Home Depot Inc, JD.com Inc Adr and Alibaba Group Holdings Ltd ADR. Therefore, these companies are considered the most competitive in its operation strategy in the current global market, whereas there are four retail companies falls into category of "inefficient" (efficiency score < 1.00), namely: Walmart, Amazon.com Inc, Tesco PLC and Walgreens Boots Alliance Inc. It is implied that these companies were unable to utilize their resources (input) to produce maximum output.

\section{Research Limitation}

This research has limitations since a number of inputs such as: number of outlets, number of product items sold and number of suppliers have not been included in the analysis. In addition, a number of non-financial performance outputs such as: market share, customer satisfaction and number of customers have also not been included in the analysis. That is because the authors are having difficulty to obtain these data. It is expected that the limitation of this research can be refined further by future researchers, and it is possible for the next researcher to increase the number of years of observation to a minimum of five years.

\section{References}

Ahmad, F. S., Ihtiyar, A., \& Omar, R. (2014). A Comparative Study on Service Quality in the Grocery Retailing: Evidence from Malaysia and Turkey. Procedia-Social and Behavioral Sciences, (109), 763-767. https://doi.org/10.1016/j.sbspro.2013.12.541

Barros, C. P. (2005). Measuring Efficiency in the Hotel Sector. Annals OfTourism Research, 32(2), 456-477. https://doi.org/10.1016/j.annals.2004.07.011

Birkinshaw, J., Morrison, A., \& Hulland, J. (1995). Structural and Competitive Determinants of a Global Integration Strategy. Strategic Management Journal, $16,637-655$.

Brealey, R. A., Myers, S. C., \& Marcus, A. J. (2018). Fundamentals of Corporate Finance (9th ed.). United States of America: McGraw-Hill Education.

Brigham, E. F., \& Houston, J. F. (2019). Fundamentals of Financial Management (15th ed.). Boston, USA: Cengage Learning.

Buleca, J., \& Mura, L. (2014). Quantification of the Efficiency of Public Administration by Data Envelopment Analysis. Procedia Economics and Finance, (15), 162-168. https://doi.org/10.1016/S2212-5671(14)00469-9

Burt, S., \& Johansson, U. (2011). Standardized Marketing Strategies in Retailing? IKEA's Marketing Strategies in Sweden, the UK and China. Journal of Retailing and Consumer Services, (18), 183-193. https://doi.org/10.1016/j.jretconser.2010.09.007

Chitnis, A., \& Mishra, D. K. (2019). Performance Efficiency of Indian Private 
Hospitals Using Data Envelopment Analysis and Super-Efficiency DEA. Journal of Health Management, 1-15. https://doi.org/10.1177/0972063419835120

Cooper, W. W., Seifod, L. M., \& Tone, K. (2006). Introduction to Data Envelopment Analysis and Its Uses With DEA-Solver Software and References. United States of America: Springer.

David, F. R., \& David, F. R. (2017). Strategic Management: A Competitive Adventage Approach (16th ed.). United States of America: Pearson Education, Inc.

Geys, B. (2006). Looking Across Borders: A Test of Spatial Policy Interdependence Using Local Government Efficiency Ratings. Journal of Urban Economics, (60), 443-462. https://doi.org/10.1016/j.jue.2006.04.002

Ginter, P. M., \& Duncan, W. J. (1990). Macroenvironmental Analysis for Strategic Management. Long Range Planning, 23(6), 91-100.

Goksen, Y., Dogan, O., \& Ozkarabacak, B. (2015). A Data Envelopment Analysis Application for Measuring Efficiency of University Departements. Procedia Economics and Finance, 19(15), 226-237. https://doi.org/10.1016/S22125671(15)00024-6

Golovko, E., \& Valentini, G. (2011). Exploring the Complementarity Between Innovation and Export for SMEs' Growth. Journal of International Business Studies, 42, 362-380. https://doi.org/10.1057/jibs.2011.2

Gong, Y. (2013). Global Operations Strategy: Fundamental and Practice. New York: Springer.

Gong, Y., Liu, J., \& Zhu, J. (2019). When to Increase Firms' Sustainable Operations for Efficiency? A Data Envelopment Analysis in the Retailing Industry. European Journal of Operational Research, (277), 1010-1026. https://doi.org/10.1016/j.ejor.2019.03.019

Gorrison, R. H., Noreen, E. W., \& Brewer, P. C. (2018). Managerial Accounting (16th ed.). New York: McGraw-Hill Education.

Hendricks, K. B., \& Singhal, V. R. (2005). An Empirical Analysis of the Effect of Supply Chain Disruptions on Long-Run Stock Price Performance and Equity Risk of the Firm. Production and Operations Management Society, 14(1), 3552 .

Hitt, M. A., Ireland, R. D., \& Hoskisson, R. E. (2017). Strategic Management: Competitiveness \& Globalization (12th ed.). Boston, USA: Cengage Learning.

Horne, J. C. Van, \& Wachowicz, J. M. (2009). Fundamentals of Financial Management (13th ed.). London: Pearson Education Limited.

IAI. (2013). PSAK 46: Pajak Penghasilan. In Pernyataan Standar Akuntansi Keuangan (November). Jakarta: Ikatan Akuntan Indonesia.

ICAEW. (2008). International Financial Reporting Standards. England: The Institute of Chartered Accountants in England and Wales (ICAEW).

Investing.com. (2020a). Alibaba Group Holdings Ltd ADR (BABA). Retrieved April 16, 2020, from https://id.investing.com/equities/alibaba-financial-summary

Investing.com. (2020b). Amazon.com Inc (AMZN). Retrieved April 16, 2020, from https://id.investing.com/equities/amazon-com-inc-financial-summary 
Competitive Environment Analysis in Global Retail Companies Operation Strategy: A

Data Envelopment Analysis (DEA) Based Approach

Investing.com. (2020c). Carrefour SA (CARR). Retrieved April 16, 2020, from https://id.investing.com/equities/carrefour-financial-summary

Investing.com. (2020d). Costco Wholesale Corp (COST). Retrieved April 16, 2020, from https://id.investing.com/equities/costco-whsl-corp-new-financial-summary

Investing.com. (2020e). Currency Converter. Retrieved April 16, 2020, from https://www.investing.com/currency-converter/

Investing.com. (2020f). Home Depot Inc (HD). Retrieved April 16, 2020, from https://id.investing.com/equities/home-depot-financial-summary

Investing.com. (2020g). JD.com Inc Adr (JD). Retrieved April 16, 2020, from https://id.investing.com/equities/jd.com-inc-adr-financial-summary

Investing.com. (2020h). Kroger Company (KR). Retrieved April 16, 2020, from https://id.investing.com/equities/kroger-co-financial-summary

Investing.com. (2020i). Tesco PLC (TSCO). Retrieved April 16, 2020, from https://id.investing.com/equities/tesco-financial-summary

Investing.com. (2020j). Walgreens Boots Alliance Inc (WBA). Retrieved April 16, 2020, from https://id.investing.com/equities/walgreen-co-financial-summary

Investing.com. (2020k). Walmart Inc (WMT). Retrieved April 16, 2020, from https://id.investing.com/equities/wal-mart-stores-financial-summary

Johlke, M. C., \& Iyer, R. (2013). A Model of Retail Job Characteristics, Employee Role Ambiguity, External Customer Mind-set, and Sales Performance. Journal of Retailing and Consumer Services, (20), 58-67. https://doi.org/10.1016/j.jretconser.2012.10.006

Jorge, M. J., Carvalho, F. A. de, Jorge, M. F., Medeiros, R. de O., \& Ferreira, D. de S. (2013). Efficiency Analysis in Public Health Organizations in Brazil. Journal of Modelling in Management, 8(2), 241-254. https://doi.org/10.1108/JM2-032010-0015

KB. (2020). Operating Cost. Retrieved April 20, 2020, from https://www.kamusbesar.com/operating-cost

KBBI. (2016). Karyawan. Retrieved April 21, 2020, from https://kbbi.kemdikbud.go.id/entri/karyawan

Ko, K., Chang, M., Bae, E., \& Kim, D. (2017). Efficiency Analysis of Retail Chain Stores in Korea. Sustainability, (9), 1-14. https://doi.org/10.3390/su9091629

Lau, K. H. (2013). Measuring Distribution Efficiency of a Retail Network Through Data Envelopment Analysis. Int. J. of Production Economics, 2(146), 598-611. https://doi.org/10.1016/j.ijpe.2013.08.008

Liu, J., Gong, Y. (Yale), Zhu, J., \& Zhang, J. (2018). A DEA-Based Approach for Competitive Environment Analysis in Global Operations Strategies. International Journal of Production Economics, (203), 110-123. https://doi.org/10.1016/j.ijpe.2018.05.029

Marketos, G., \& Theodoridis, Y. (2006). Measuring Performance in the Retail Industry. Springer-Verlag Berlin Heidelberg, (September), 129-140. https://doi.org/10.1007/11837862

Mertens, W., Recker, J., Kummer, T., Kohlborn, T., \& Viaene, S. (2016). Constructive Deviance as a Driver for Performance in Retail. Journal of Retailing and 
Consumer

Services,

30 ,

$193-203$

https://doi.org/10.1016/j.jretconser.2016.01.021

Ohsato, S., \& Takahashi, M. (2015). Management Efficiency in Japanese Regional Banks : A Network DEA. Procedia - Social and Behavioral Sciences, (172), 511-518. https://doi.org/10.1016/j.sbspro.2015.01.394

Pang, M., Tafti, A., \& Krishnan, M. (2013). Information Technology and Administrative Efficiency in U.S. State Governments: A Stochastic Frontier Approach. MIS Quarterly, 38(4), 1-59. https://doi.org/10.2139/ssrn.1612820

Panigyrakis, G. G., \& Theodoridis, P. K. (2007). Market Orientation and Performance: An Empirical Investigation in the Retail Industry in Greece. Journal of Retailing and Consumer Services, 137-149. https://doi.org/10.1016/j.jretconser.2006.05.003

Prakash, V., \& Annapoorni, D. (2015). Performance Evaluation of Public Hospitals in Tamil Nadu. Journal of Health Management, 17(4), 417-424.

Ragsdale, C. T. (2008). Spreadsheet Modeling and Decision Analysis (5th ed.). Mason, USA: Thomson Corporation.

Ragsdale, C. T. (2018). Spreadsheet Modeling and Decision Analysis (8th ed.). Boston, USA: Cengage Learning.

Ramanathan, R. (2003). An Introduction to Data Envelopment Analysis, A Tool for Performance Measurement. New Delhi: Sage Publication.

Ross, S. A., Westerfield, R. W., Jaffe, J. F., \& Jordan, B. D. (2018). Corporate Finance: Core Principles \& Applications (5th ed.). New York: McGraw-Hill Education.

Russo, M. V, \& Fouts, P. A. (1997). A Resource-Based Perspective on Corporate Environmental Performance and Profitability. Academy of Management Jauma, 40(3), 534-559. https://doi.org/10.2307/257052

Sanjeev, G. M. (2007). Measuring Efficiency of the Hotel and Restaurant Sector: the Case of India. International Journal of Contemporary Hospitality Management, 19(5), 378-387. https://doi.org/10.1108/09596110710757543

Scarborough, N. M., \& Cornwall, J. R. (2016). Essentials of Entrepreneurship and Small Business Management (8th ed.). Harlow, England: Pearson Education Limited.

Singh, A. K. (2011). Performance Evaluation of Indian Airline Industry: An Application of DEA. Asia-Pacific Business Review, VII(2), 92-103.

Slater, S. F., \& Narver, J. C. (1994). Does Environment Competitive Moderate the Market Orientation-Performance Relationship? Journal of Marketing, 58(January), 46-55.

Storto, C. I. (2013). Evaluating Technical Efficiency of Italian Major Municipalities: A Data Envelopment Analysis Model. Procedia and Behavioral Science (Elsevier-Science Direct), (81), 346-350.

Sufian, F., Kamarudin, F., \& Nassir, A. M. (2016). Determinants of Efficiency in the Malaysian Banking Sector : Does Bank Origins Matter? Intellectual Economics, (10), 38-54. https://doi.org/10.1016/j.intele.2016.04.002

Taylor III, B. W. (2016). Introduction to Management Science (12th ed.). Harlow, England: Pearson Education Limited. 
Competitive Environment Analysis in Global Retail Companies Operation Strategy: A

Data Envelopment Analysis (DEA) Based Approach

Ward, P. T., \& Duray, R. (2000). Manufacturing Strategy in Context: Environment, Competitive Strategy and Manufacturing Strategy. Journal of Operations Management, (18), 123-138.

Wheelen, T. L., Hunger, J. D., Hoffman, A. N., \& Bamford, C. E. (2018). Strategic Management and Business Policy: Globalization, Innovation and Sustainability (15th ed.). Harlow, England: Pearson Education Limited.

Yu, W., \& Ramanathan, R. (2008). An Assessment of Operational Efficiencies in the UK Retail Sector. International Journal of Retail \& Distribution Management, 36(11), 861-882. https://doi.org/10.1108/09590550810911656

Zhonghua, C., \& Ye, W. (2012). Research Frontiers in Public Sector Performance Measurement. Physics Procedia, (25), 793-799. https://doi.org/10.1016/j.phpro.2012.03.159

Zhu, J. (2011). Airlines Performance via Two-Stage Network DEA Approach. Journal of CENTRUM Cathedra, 4(2), 260-269. 